\title{
Selling Concept: Strategy for Improving the Marketability of Nigerian World Heritage Sites
}

\section{Areo Adebowale Biodun Ph.D}

Wesley University of Science and Technology, College of Social and Management Science, Department of Management Science Ondo, Ondo State, Nigeria; Email: talk2areo@yahoo.com.or talk2areo@gmail.com

\section{Doi:10.5901/ajis.2015.v4n3p149}

\begin{abstract}
The Nigerian World Heritage Sites are experiencing a low turn-out of tourists, visitors, researchers and Nigerian dignitaries. The sites are hardly known outside their area of existence. Their international recognition and importance bears no significance to many. This paper therefore examines the root causes of Nigerians' lukewarm attitude to these sites. Through systematic and purposive sampling techniques, 150 respondents in 10 villages of 5 selected Local Government Areas were sampled. A structured interview schedule was used in the collection of data administered through the heritage Site manager and his staffers. For clarification of responses, unstructured interview and physical condition and linguistic observation were used to support the interview schedule. The result of the analysis showed a positive correlation between awareness level and people visiting the sites. The awareness for the existence and new status of these two sites were low or none existence. Among the five competing marketing philosophies, the application of selling concept comprising of advertisement, promotion, personal selling and public relation was found to be more appropriate in creating awareness. The paper concluded by recommending other marketing principles that can ensure the maximum use of these two sites thereby fulfilling the real purpose of their new status and bringing in foreign exchange.
\end{abstract}

Keywords: Advertisement; Marketing Promotion; Selling Concept; Strategy; World Heritage Site.

\section{Introduction}

World Heritage Sites are places of significant, historic and cultural value throughout the World. They are carefully selected for preservation by the World Heritage Committee. The World body which is an inter-governmental organization is responsible for cataloguing and protecting World Heritage Sites, and operates under the direction of the United Nations Educational, Scientific and Cultural Organization (UNESCO). World Heritage Sites represents areas that are particularly ingenious and deserve to be taken into consideration in the search for solutions to today's challenges (Eborieme, 2008: 22-27). Collectively, the rich diversity of African heritage contributes a unique wealth to World Heritage (Adedayo, 2004: 61). The study of these heritage sites makes it possible to better understand today's world and to better prepare for the future, (Adediran, 2008: 49-58). Communities are therefore encouraged to preserve and valorize this heritage that represents the core of their common identity.

Tidjani-Serpos (2006: 7) argues that these heritage sites are supposed to contribute every day to the quality of life of the Nigerian and African communities. Elong-Mbassi (2006: 5) opines therefore that Africans need to pay attention and interest to their cultural heritage sites. Enhancing the cultural and heritage values within Nigeria and Africa, would reinforce the cultural dimension, and would undoubtedly upgrade the living condition of Nigerians especially in and around where these sites are (Osuagwu 2008). Nigeria currently has two World Heritage Sites on this prestigious list. The two World Heritage Sites are located in Sukur in Madagali Local Government area of Adamawa State, and Osogbo, in Olorunda Local Government Council of Osun State (plates 1- 3). They were approved for this prestigious list in the year 1999 and 2005 respectively. Yusuf (2008) is of the view that "very few Nigerians or Africans are aware of the World Heritage Convention and Heritage Sites. He empathizes, that there is a "split" which as is the case for other sector of the economy and society puts Africa at risk of being marginalized." He further lamented that many local people called stakeholders have not yet taken stock of the existence and potential offered by the heritage sites." These cultural heritage sites are presently facing major challenges linked to human development. 


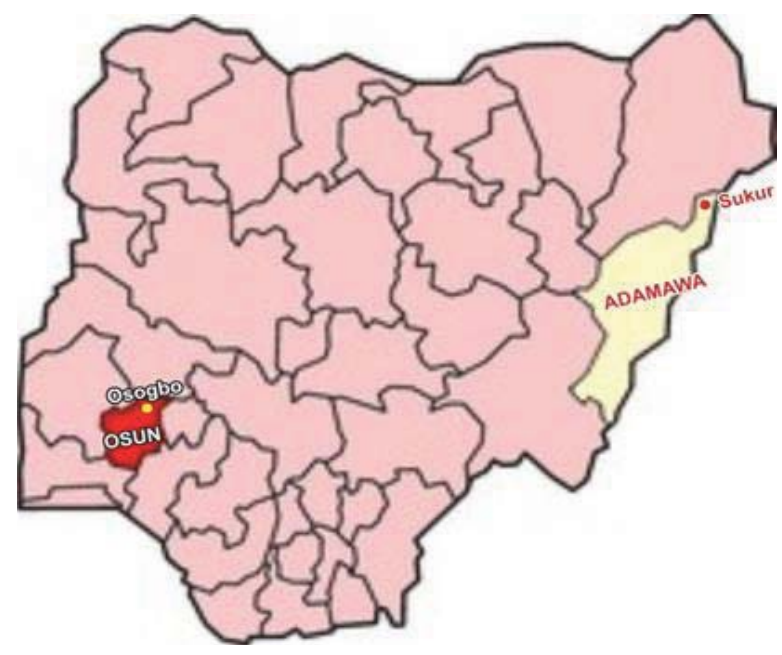

Plate 1: Map of Nigeria showing World Heritage Sites at Sukur in Adamawa State and Osun Osogbo in Osun State.

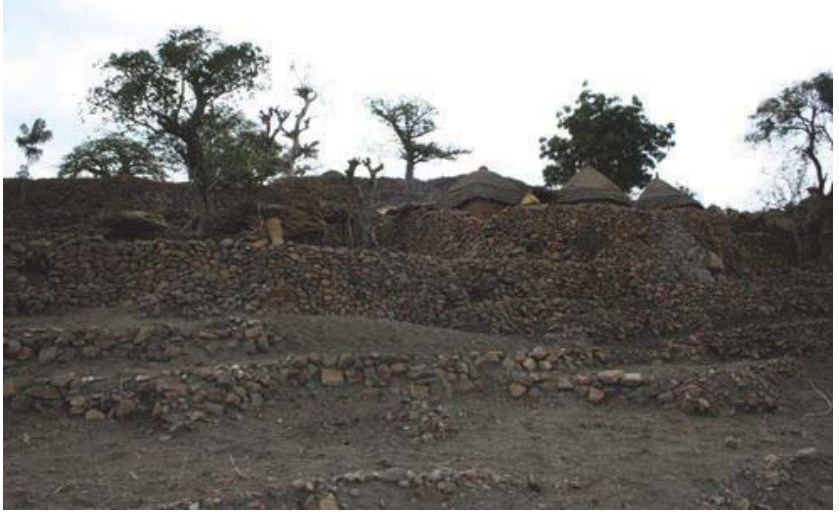

Plate 2: Landscape of World Heritage Site at Sukur, Adamawa State

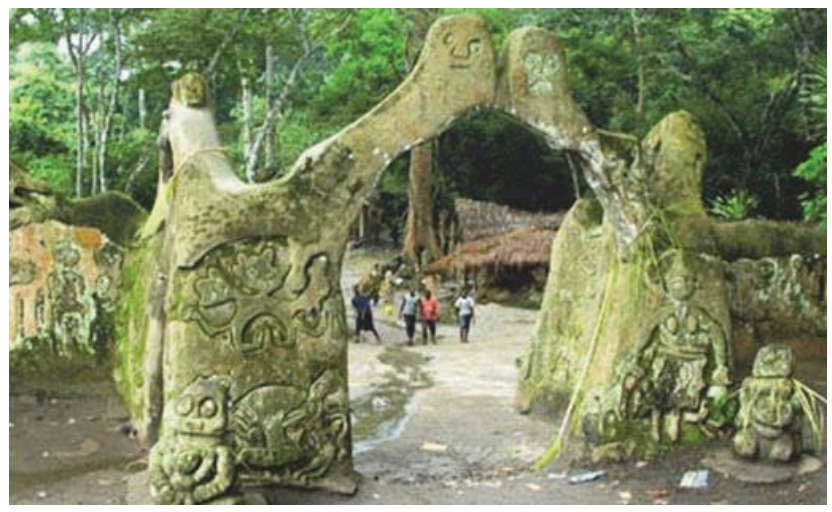

Plate 3: Landscape of World Heritage Site at Osogbo, Osun State 
Despite undeniable qualities that earned these sites a listing in the prestigious World Heritage List, the sites are not being patronized as expected. Ten years annual reports (2002-2011) of visitors to the sites from the Education department of the National Commission for Museums and Monuments showed that visitor-ship is either not increasing or is on the decline. Yorke and Jones (2006: 94) pointed out that, "the promotion of Museums and Heritage Sites services would enhance the stimulation of excessive demand." Applying marketing principles such as selling concept has been variously ignored by successive Heritage Managers because of the fear of the carrying capacity of the two World Heritage Sites. However, Yorke and Jones (2006:94) were of the opinion that fear of the consequences of a marketing orientation is no justification for ignoring it. The duo explains that, what such heritage managers fails to realize is that the proper application of marketing thought and techniques could lead to either provision of those sought after development or better still, an increased number of atisfied customers/segments without any increase in existing resources. This is why this paper presents a marketing model - selling concept as a way of arresting this decline and to also stimulate the patronage of these two sites. Selling concept was propounded by Kotler and Keller (2012:17-18) and is a time tested tool that ensures that products being shunned by prospective consumers becomes enticing to them to patronize. The Management Plans of Sukur Cultural Landscape 2012-2016, and Osun Osogbo Cultural Landscape have, as one of their objectives, proposals to effectively carry out promotional activities as a means of creating awareness within and without the World Heritage Sites. While it is the responsibility of the World Heritage Committee to set general objectives for declared Sites, the onus rests on the country that owns the sites to set strategies on how the site would be maximally utilized by its citizenry and the world at large.

Strategy is a plan that intended to achieve a particular purpose (Hornby 2005). It is a well known fact that many organizations have revolutionized their functions through the application of marketing and marketing principles. Marketing is a social and managerial process by which individual and groups obtain what they need and want through creating and exchanging products and value with others (Kotler and Keller 2012). Well-developed marketing strategies and tactics are usually put in place as a means of achieving customer's take-up of a service.

The two World Heritage Sites in Nigeria are not being patronized as it should be. A preliminary investigation reveals plethora of reasons which include lack of awareness of their existence.

\section{The Research Objective}

The specific objective of the study was to investigate the snobbish attitude of tourists, local and foreign alike towards the two hard won World Heritage Sites in Nigeria. It aimed at determining the factors hindering tourists, local visitors and foreign ones from patronizing and savouring the various wonderful products that makes the sites worthy of inclusion in the significant prestigious World Heritage Sites.

\section{Research Study}

The research is focused on the two World Heritage Sites (WHS) declared in favour of Nigeria. They are the Sukur Cultural Landscape located in Madagali Local Government Council in Adamawa State, and Osun-Osogbo Cultural Landscape located in Osogbo Local Government Council both in Nigeria. The two sites are managed by the National Commission for Museums and Monuments (NCMM) an agency of Federal Government of Nigeria. In the management of the two sites, there are five levels of responsibility. They are the stakeholders (Local Governments and adjoining villages in five Local Governments), the site management, the education unit, the site guides and site guards.

\section{The Sample Response}

A random sample was drawn systematically for each site, at each level using the sites annual visitors' report or statistics and other publications on the management structure of sites as sample frame. A total of one hundred and fifty (150) questionnaires were distributed using the site guides, education officers and managers, one hundred and five (105) usable responses were obtained. 
Table 1: Composition of Sample and Responses

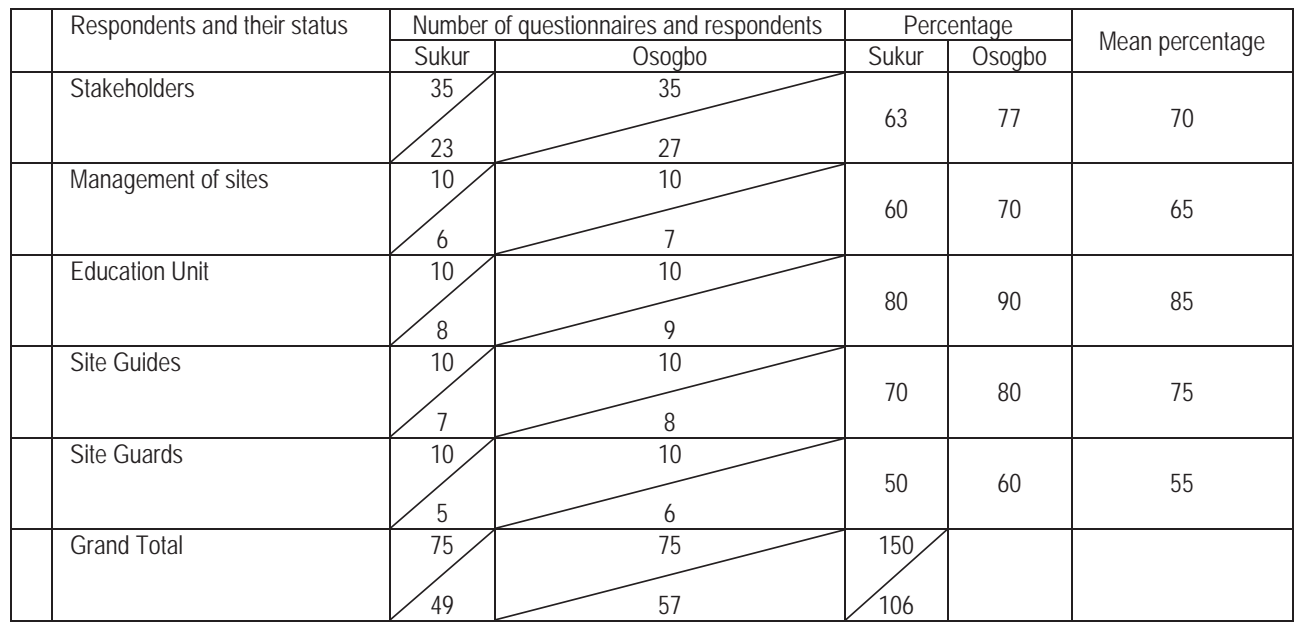

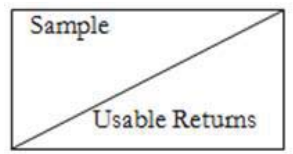

Source: Survey 2013, table adapted from Watson (1982)

Table 1 gives the details of the composition of the sample and their responses. For clarification of responses among the stakeholders, unstructured interviews and physical condition and linguistic observation were used to support the interview. The response from the stakeholders and its five adjourning local governments for Sukur was $63 \%$ and Osogbo was $77 \%$, and a mean of $70 \%$ was considered satisfactory. In several cases, failure to respond was explained by ignorance of the people in the two sites. At the site guides level, the response was observed to be higher than those of the stakeholders. This is probably because they are educated and know the value of the research. In Sukur WHS 70\% responded, while in Osogbo WHS, $80 \%$ responded given a mean of $75 \%$ for the two sites. This percentage was also considered very satisfactory.

The Education Officers' level with $80 \%$ response from Sukur WHS and 90\% from Osogbo WHS and a mean of $85 \%$ was the most satisfactory. It is probably to be expected because they educate the visitors to the sites of the importance of the two sites to humanity.

At the site guards level the response from the two sites were the lowest. With Sukur WHS having $50 \%$ response while Osogbo WHS, had 60\%. Notwithstanding these low returns among others, the returns were considered satisfactory. The reason for the low responses is expected because these people are illiterates and could only understand and answer the questionnaires through interpreters. They have little or no knowledge of what the research was aiming to achieve. At the management of site level, the response was lower with 60\% from Sukur WHS and 70\% from Osogbo WHS and mean of $65 \%$ was surprisingly lower than expected.

\section{The Questionnaires}

The questionnaires consisted of twenty five statements inviting response on a five point likerts scale. The questions were divided into four parts representing the four components of selling concepts which are: advertisement, sales promotion, personal selling and public relations as tool for creating awareness for the two World Heritage Sites. The four sections deal with:

$>$ The possible impact of advertisement in drawing attention of tourists, students, children and researchers to the sites. 
$>$ The effect of supporting advertisement with sales promotion.

$>$ About developing interactive relationship through personal selling.

$>$ On the issue of building image for the two World Heritage Sites through Public Relations.

\section{Reservations on the interpretation of Results}

There were evidences of misinterpretation of questionnaires to some illiterate stakeholders, this will surely either slightly increase or decrease the response percentages recorded. Also management responses were biased because they were trying to paint a positive picture of the two sites in terms of visitor's patronage.

\section{Research Findings}

\subsection{Possible Impact of Advertisements in creating awareness for the two World Heritage Sites.}

The stakeholders or $74 \%$ respondents from Sukur World Heritage Site scored low any form of advertisement of the site. They were unequivocal that advertisement with all its components: radio, television, newspapers, flyers, outdoor billboards etc were none in existence. 18\% were undecided, while $8 \%$ felt there was enough advertisement.

In their ranking of the advertisement components, Sukur WHS respondents ranked radio highest $80 \%$ as the most effective means of creating awareness, with television coming next with $18 \%$ and others $2 \% .78 \%$ Osun WHS respondents viewed advertisement as not existing, 12 were undecided and $10 \%$ were of the view that was advert

Respondents from Osun World Heritage Site, scored radio advertisement very high 85\%, while television was scored $14 \%$ and other advertisement components $1 \%$.

\subsection{Sales Promotion}

The majority of respondents from Sukur World Heritage Sites scored sales promotion generally low with $28 \%$ saying that sales promotional tools were enough. There were $12 \%$ who were undecided about the availability of sales promotional tools. However an overwhelming majority $66 \%$ opined that the tools were neither unused nor available. In ranking sales promotional tools, most of the respondents $78 \%$ ranked consumer promotion higher, while sales force promotion was ranked next $20 \%$, and trade promotion $2 \%$.

In Osun World Heritage Site, majority of respondents also scored sales promotion low with $72 \%$ saying that there was no sales promotion put in place by management of the site, $18 \%$ were undecided, while $10 \%$ were of the view that sales promotion was enough to create necessary awareness. In ranking Sales Promotion components, $74 \%$ ranked consumer promotion highest, while $18 \%$ ranked sales-force as the best, while $8 \%$ ranked trade promotion as best.

\subsection{Personal Selling}

Respondents in the WHS were overwhelming in their submissions that the two sites are extremely alienated from the community where they are located. As a result of this, $78 \%$ of the respondents from Sukur WHS scored personal selling very low, $14 \%$ of the respondents were undecided, while $8 \%$ scored personal selling high. On the other hand, $71 \%$ of Sukur WHS respondents would wished a strong relationship be developed between the stakeholders, the visitors and the management of the site as a way of creating and sustaining awareness for the site, there were $18 \%$ respondents who were undecided, while $11 \%$ know nothing about the issue at stake .

In Osun World Heritage Site, 91\% of the respondents scored personal selling low, and 7\% were undecided, while $2 \%$ were not bordered about what was going on in the site. However, $80 \%$ respondents subscribed to having a strong relationship developed between the stakeholders, visitors and the site management, while $18 \%$ were undecided and $2 \%$ were not in the picture of what the site stands for globally.

\subsection{Building an Image for the Sites through Public Relation}

There were general agreement the two WHS required developing good and strong image around them. As a result in Sukur World Heritage Site, $75 \%$ of the respondents were of the view that the management of the site have not built good image for the site to ensure continuous visits of visitors to the site. There were $21 \%$ respondents who felt the image of the 
site can be bettered by the management of the site, while $4 \%$ do not know about what management of the site was doing to enhance the image of the site.

In Osogbo World Heritage Site, $68 \%$ of the respondents were of the view that the management of the site was not doing enough to develop strong image for the site. There were $20 \%$ respondents who viewed the site as popular enough basing their judgment on the high turnover of people during Osun-Osogbo Annual Festival; however, $12 \%$ respondents strongly disagreed that the site is only popular for it fetish activities.

\section{Discussion of Results}

Findings revealed that the two sites were largely under-publicized to Nigerians and the World at large. The general apathy to the sites is traceable to lack of awareness of the existence and new statuses of the two World Heritage Sites. For example, radio advertisement is considered to have far reaching effect because of the wide coverage of signals. It was also argued that more than 20million of Nigerians have mobile phones with radio on them. (Nigerian Communication Commission, 2011) Also, bush pocket radios are cheap and preponderant with rural and urban dwellers. The respondents wondered why management of these WHS is not taking advantage of this very important, omnipresent advertisement tool. Radio also has the advantage of being listened to by many than television. Television purchase is prohibitive as well as advertising on them. For Newspapers, majority of the stakeholders were observed to be illiterate so newspapers were out of the question.

The respondents were quick to say that sales promotion such as rebates on group visits, patronage, rewards were not in existence. They would discounts on tickets, allowance for loyal clients and vigorous sales-force promotion should be put in place.

On personal selling, the respondents were of the view that as it were, the management of the sites have succeeded in alienating the community from their sites making them elitist. They were against the restricted movements in the two World Heritage Sites.

The findings on public relations show that the image of the two World Heritage Sites is poor and needed to be 'polished', for example the Christians and Moslems in Osogbo and its environs, view the Osogbo World Heritage Site as an idol worshipping centre. They saw fetish activities as being the core function of the site. In the same vein, the Sukur World Heritage Site was seen as being occupied by fetish people who are called in derogatory language as pagans. The Christians and Moslems hardly visit the two World Heritage Sites on these bases.

In line with this study Hawkins, Best, \& Cooney (2001: 306-307) explain that in creating awareness for products using media strategy, "the proper approach is to determine to which media the consumers in the target market are frequently exposed to, and then place the advertising messages in those media". This view was corroborated by the executive of the Ford $(1981,307)$, when he says that "we must look increasingly for matching media that will enable us best to reach carefully targeted emerging markets. The riffle approach rather than the old shortgun approach".

In summary, selling concept and its components: adverts, promotion and public relations must be properly evaluated to know which of them will suit a particular target market in the creation of necessary awareness. Since media such as radio and television are well patronized, Hawkins et al (2001) are saying that heritage managers of these sites as the marketers must find media that the target market is interested in and place appropriate advertising message in those media.

\section{Suggestions and Conclusion}

In order to move the awareness creation of Nigeria's two sites to the next level, Management of the sites must be proactive by providing brochures and strategically place them free of charge in all our land, sea and airports for foreigners coming into Nigeria.

Apart from this, striking features of the two sites should be displayed in large pictorial posters in all our ports to catch the attention of would - be - visitors from outside the country. Large designated billboards should be made by the National Commission for Museums and Monuments to promote the two sites. Handbills should be mass produced to be distributed at motor parks, schools, universities and churches to attract visitor.

The Commission should liaise with the Ministry of Education to ensure that visits to museum and our World Heritage Sites are included in the curriculum of schools at primary and secondary levels. CD's, DVD's and tapes of happenings in the two sites should be played at all our ports and should be available for sale. 


\section{References}

Adedayo, O. F. (2004) Osun Osogbo Sacred Grove: in Africa 2009 Projects Siitue's 10 Years of Field Experience. Pp. 121 - 127.

Adedayo, O. F. (2006) Conservation, Osun Osogbo Sacred Grove, Nigeria: in, A Guide for Cultural Heritage and Local Development. Publ. by CRATerre - ENSAG/Convention France - UNESCO. P.61

Adediran, N. M. (2008) Practical Aspects of Heritage Conservation and Management in Nigeria. In .Zainab Ali Biu (Coordinator). Conservation and Management of Heritage Sites in Nigeria. Abuja, UNESCO. Pp. 49-58

Eboreime, O.J. (2008) Understanding Cultural Sites and the Preparation of Nomination Dossier for World Heritage Listing. In Zainab Ali Biu (Coordinator). Conservation and Management of Heritage Sites in Nigeria. Abuja, UNESCO. Pp.22- 27.

Elong -Mbass, J. P. (2006) The Different Types of Heritage: A guide for Cultural Heritage and Local Development. France, CRATerre ENSAG/Convention - UNESCO.Pp.7.

Ford Boss Outlines Shift to 'Rifle' Media (1981)," Advertising Age” p 89

Hawkins,D.I, R,J. Best \& K,A.Coney (2001) Consumer Behaviour: Building Marketing Strategy. New York, Irvine/Mcgraw-Hill, Pp306307

Hornby, A.S (2005). Oxford Advanced Learner's Dictionary, Oxford University Press. $7^{\text {th }}$ Edition International Student's Edition. P. 1461

Kotler, P and K.L Keller (2012).Marketing Management, Prentice Hall Person Education Limited. P 17 - 18

National Commission for Museums and Monuments in conjuction with UNESCO. (2011). Osun Osogbo Sacred Grove (2010 - 2014) : Conservation Management Plan. Abuja Pp. 50 - 53.

National commission for Museums and Monuments with support from UNESCO.(2011).Sukur Cultural Landscape conservation Management Plans 2012 - 2016. Abuja

Nigerian Communication Commission. (2011). The State of of Telecommunication in Nigeria. The Nigerian Daily Tribune, $25^{\text {th }}$ July. P. 19.

Osuagwu, V. N. (2008), Introduction to Heritage Conservation and Site Management: In . Biu Z. A. (Coordinator) Conservation and Management of Heritage Sites in Nigeria. Abuja. UNESCO Pp. $13-14$.

Tidjani - Serpos, N. (2006) what is Heritage? A guide for Cultural Heritage and Local Development. Publ. by CRATerre ENSAG/Convention France - UNESCO. Pp. 5 - 9.

Yorke, D. A. and R. R. Jones (2007) Marketing and Museums: European Journal of Marketing 18 . 2. Pp. $90-95$.

Yusuf A. U. (2008) Heritage Management: An Introduction "in Conservation Management of Heritage Sites in Nigeria. Pp. 4 - 5. 
